\title{
原著
}

\section{腹膜透析患者における腹腔鏡所見 一特に被囊性腹膜硬化症の病態一}

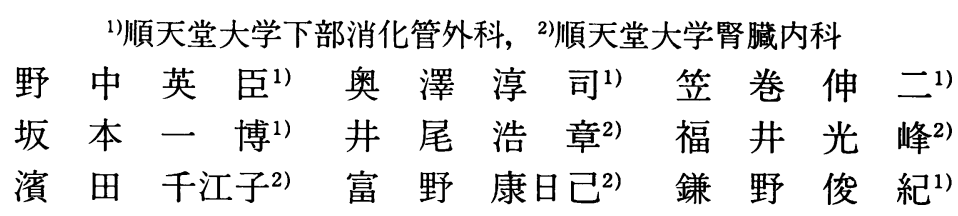

\section{Laparoscopic Findings in Peritoneal Dialysis Patients -Especially The Study of Encapsulating Peritoneal Sclerosis-}

Eishin NONAKA ${ }^{1)}$, Jyunji OKUZAWA ${ }^{1)}$, Shinji KASAMAKI ${ }^{11}$, Kazuhiro SAKAMOTO'), Hiroaki IO $^{2)}$, Mitsumine Fukui ${ }^{2)}$, Chieko HAMADA ${ }^{2)}$, Yasuhiko TOMINO $^{2)}$ and Toshiki KAMANO ${ }^{1)}$

${ }^{1)}$ Department of Coloproctrogical Surgery, Juntendo University School of Medicine

${ }^{2)}$ Division of Nephrology, Department of Internal Medicine, Juntendo University School of Medicine

目的：腹膜透析に伴う腹膜の変化を腹腔鏡を用いて肉眼的に観察, 検討した。さらに被䡬性腹膜硬化症 (encapsulating peritoneal sclerosis, 以下EPS）の病態について臨床病理学的に検討した。对象：1996年から2005年ま でに腹腔鏡下に腹膜透析カテーテル抜去を施行した32例を対象とした。方法：腹膜透析カテーテルを抜去時に観 察した腹腔鏡所見をもとに, 臨床病理学的所見と腹膜病理所見について検討した。結果：腹腔鏡所見でEPSと診 断されたのは32例中 4 例（12.5\%）であった (EPS群)。EPS群とNEPS群（EPSと診断されなかった28例）の間 に腹膜透析歴, 腹部CT検査で腸管漿膜の石灰化, 腹腔鏡所見で腸管の肥厚·癒着, 腹膜病理所見で硝子化に有意 な差が認められた。結語：腹腔鏡を用いることは腹膜透析による腹膜の変化を肉眼的に確認することができ， EPSの病態検討に有用であった。

索引用語 : 腹膜透析 (peritoneal dialysis), 被輁性腹膜硬化症 (encapsulating peritoneal sclerosis), 腹腔鏡 (laparoscope)

\section{緒 言}

慢性腎不全患者における治療の一つに腹膜透析 療法 (continuous ambulatory peritoneal dialysis；以下, CAPD) がある。しかし，これを 長期にわたり続けると腹膜劣化状態に陥りCAPD 継続が困難となる場合がある。このような場合, CAPDを中止し血液透析 (Hemodialysis；以下, HD)に移行しなくてはならない。最近，内視鏡外
科手術の普及によりCAPD患者の腹腔鏡所見に関 する報告が散見されるようになったが，実際に CAPD患者の腹腔内を腹腔鏡を用いて肉眼的に観 察している報告は少ない1)。当教室では腎臓内科 とともに，1996年からCAPDカテーテル抜去を腹 腔鏡下で施行しており, 併せて腹膜の性状, 腸管 癒着の程度, 腹水の有無・性状などを詳細に観察 している。

一方で, 長期にわたり腹膜透析を施行している 

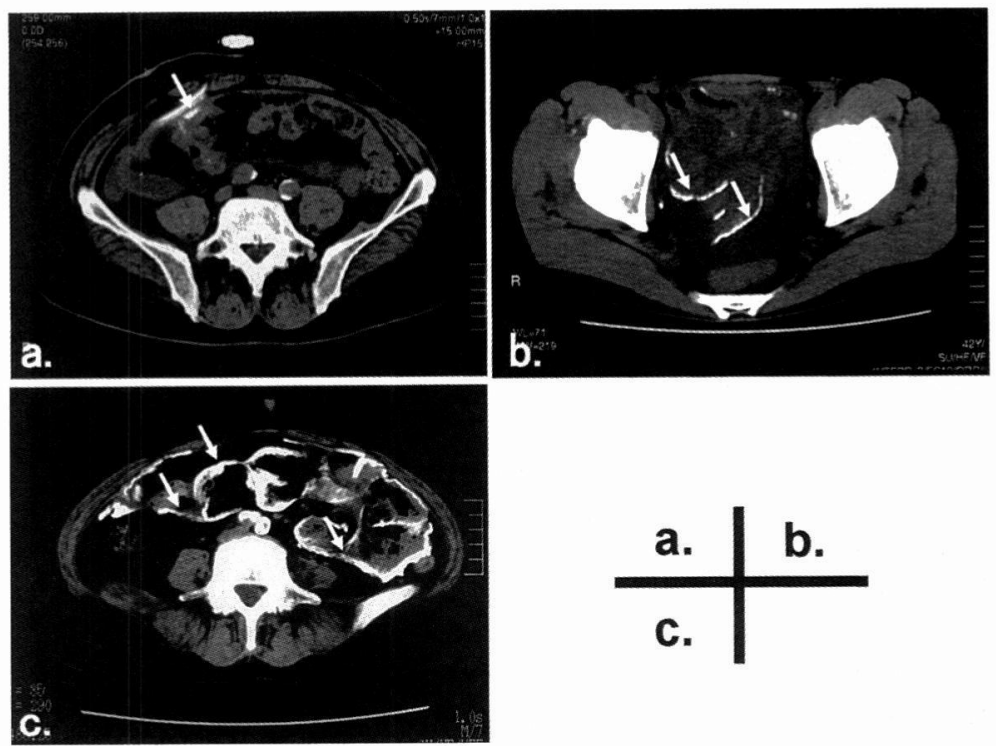

Fig. 1 abdominal CT findings of patients with peritoneal dialysis.
a. mild calcification
b. moderate calcification
c. severe calcification

と, 重篤で予後不良とされている合併症, すなわ ち被囊性腹膜硬化症（encapsulating peritoneal sclerosis；以下, EPS) または硬化性被囊性腹膜炎 (sclerosing encapsulating peritonitis ; SEP) と いわれる症候群に至る場合がある。

EPSの診断は，野本らが報告した“硬化性被囊 性腹膜炎診断・治療指針 (案) ”2)によると「臨床症 状でイレウス症状が必発である」とされており， 画像診断としてX線検査ではegg shell状に腹膜表 面に広範な薄い石灰化, 超音波検査では塊状の腸 管ならびに網状の析出物, CT検査においては腹膜 に石灰沈着を認めることもあるとされている。し かし, 画像診断はあくまで補助的診断であり，そ の確定診断にはイレウス発症例の手術時や剖検に よる肉眼的所見などから確認されることが多い。

今回, われわれはCAPD患者の画像所見に腹腔 鏡による肉眼的所見を加味し, EPSの病態につい て臨床病理学的に検討したので報告する。

\section{対象および方法}

1996年10月から 2005 年 4 月の間にCAPDカテー テル感染, 除水不良を理由に腹腔鏡を用いて CAPDカテーテル抜去を施行した32例について，
以下の項目について検討した。

\section{1. 臨床病理学的所見}

a. 患者背景因子：年齢, 性別, 腹膜透析歴 (力 月), CAPDカテーテルによる腹膜炎 (細菌性, 真 菌性）既往の有無を検討した。

b. 腹部CT検査所見：石灰化の程度を以下の 3 群に分類した。

軽度：CAPDカテーテル刺入部もしくは腸管漿 膜の極一部の石疢化 (Fig. 1a)。

中等度: 腸管漿膜の $2 \sim 3$ ループの石灰化 (Fig. 1b)。

高度：腸管漿膜の 4 ループ異常の広範な石灰化 (Fig. 1c)。

c 、腹腔鏡所見：岩本 ${ }^{1)}$ が報告した“CAPD患者 の腹腔鏡所見”を参考に以下の所見を観察した。

カラメル化：腸管漿膜が黄褐色の色調変化をき たした所見 (Fig. 2a)。

肥厚：腸管漿膜がなめし皮様の肥厚した所見 (Fig. 2b)。

被囊化：腸管漿膜が白色のフィブリン被膜に覆 われた所見 (Fig. 2c)。

癒着：フィブリン被膜により腸管同士がくっつ いた所見 (Fig. 2d)。 


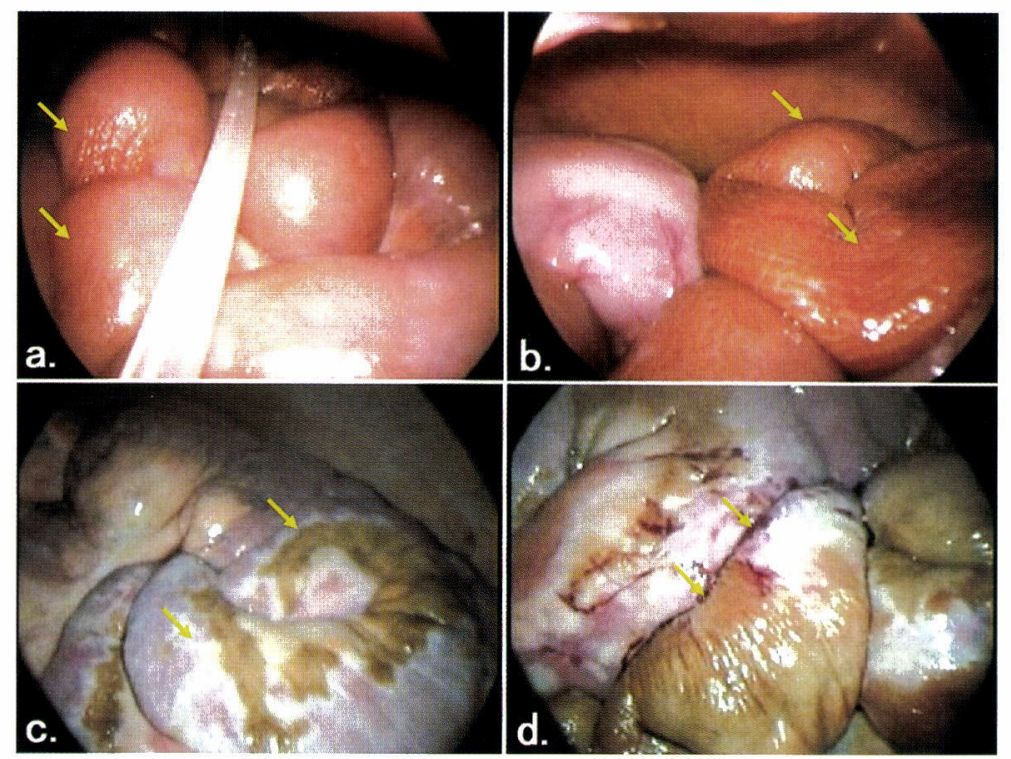

Fig. 2 laparoscopic findings of patients with peritoneal dialysis.
a. caramel change
b. thickening
c. encapsulation
d. adhesion

d. 腹膜病理所見：CAPDカテーテル抜去施行 時に採取した壁側腹膜について, Masson-Tricrome染色による（コントロール，Fig. 3a）線維 化 (Fig. 3b), ならびに硝子化 (Fig. 3c) の有無に ついて検討した。

\section{2. 腹腔鏡下CAPDカテーテル抜去方法}

$\mathrm{CAPD}$ カーテル抜去方法は坂本ら ${ }^{3)}$ が報告し た“腹腔鏡下腹膜透析カテーテル再留置術の経験” をもとに行った。すなわち，患者の体位を仰臥位 とし，全身麻酔下で臍下部に小切開を加え（この 際に腹膜を採取し, 病理検査に提出する), 同部よ り腹腔鏡用トロッカー（直径 $12 \mathrm{~mm}$ ) を挿入する。 炭酸ガスで気腹 $(6 \sim 8 \mathrm{mmHg})$ 後, 腹腔鏡で腹 腔内の観察, カテーテルと腹腔内臓器との癒着の 有無を確認する。カテーテルの全貌が確認できな い場合, 腹膜透析カテーテル㨂入部と対側の下腹 部に処置用トロッカー（直径 $5 \mathrm{~mm}$ ) を挿入し, カ テーテルの全貌を確認し, 安全にカテーテルを抜 去する。

\section{3. 統計解析}

統計解析は, Dr. SPSS IIソフトエアを用いて, $\mathrm{x}^{2}$ 検定およびMann-Whitney U検定を行い $\mathrm{p}<$ 0.05で有意差ありとした。

\section{成 績}

1) 臨床病理学的所見の検討：Table 1 に今回, 腹腔鏡を用いてCAPDカテーテルを抜去した32例 について臨床病理学的所見の結果を示す。

a . 患者背景因子：患者の平均年齢は $48.2 \pm$ 11.5歳, 男女比は24：8, 平均CAPD歴は88.6土 50.8 力, 腹膜劣化や硬化を起こす原因の一つと されている腹膜炎既往歴のあった症例は14例 (43.8\%) であった。

b . 腹部CT検査所見：腸管漿膜に石灰化を認 められた症例は, 軽度：1例 $(3.1 \%)$, 中等度： 3 例 $(9.4 \%)$, 高度：1例（3.1\%）であった。

c . 腹腔鏡所見 : 腸管漿膜のカラメル化を 10 例 $(31.3 \%)$, 肥厚を 6 例 $(18.8 \%)$, 被囊化を 4 例 $(12.5 \%)$, 癒着を 3 例 $(9.4 \%)$ に認められた（重 複例あり)。

d. 腹膜病理所見 : 壁側腹膜の病理像で, 線維 化を30例 (93.8\%), 硝子化を 9 例 (28.1\%) に認 められた(重複例あり)。

今回, 腹腔鏡を用いてCAPDカテーテルを抜去 した32例中, イレウス症状などの臨床症状からで はなく, 腹腔鏡の肉眼所見より腸管漿膜に被囊化 


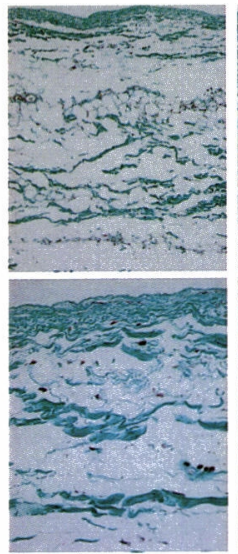

a.

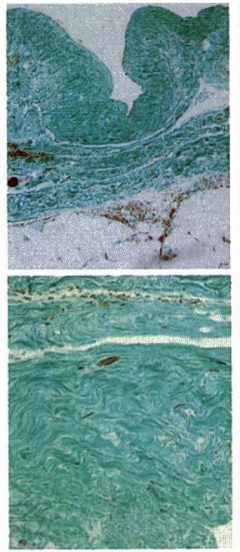

b.

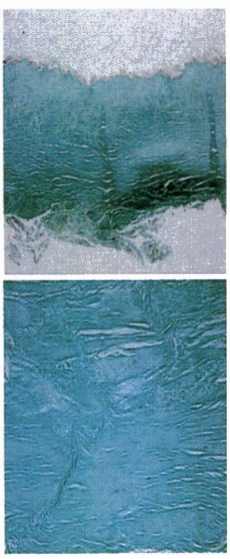

c.
Fig. 3 pathological findings in peritoneum with peritoneal dialysis.

(Masson-Tricrome)

a. control (peritoneum without peritoneal dialysis)

b. fibrosis

c. hyalinization

(the upper row $\times 100$, the lower row $\times 400$ ).

Table 1 Clinicopathological results of patients $(n=32)$

\begin{tabular}{lc}
\hline Age & $48.2 \pm 11.5$ \\
Gender Male : Female & $24: 8$ \\
History of CAPD (months) & $88.6 \pm 50.8$ \\
Past history of peritonitis & $14(43.8 \%)$ \\
Abdominal CT findings & \\
$\quad$ mild calcification & $1(3.1 \%)$ \\
$\quad$ moderate calcification & $3(9.4 \%)$ \\
$\quad$ severe calcification & $1(3.1 \%)$ \\
Laparoscopic findings & \\
$\quad$ caramel change & $10(31.3 \%)$ \\
$\quad$ thickening & $6(18.8 \%)$ \\
$\quad$ encapsulating & $4(12.5 \%)$ \\
$\quad$ adhesion & $3(9.4 \%)$ \\
Pathological findings of peritoneum & \\
$\quad$ fibrosis & $30(93.8 \%)$ \\
$\quad$ hyalinization & $9(28.1 \%)$ \\
\hline
\end{tabular}

を認めたものをEPSと定義したところ，4 例に被 囊化を認められた(EPS群)。これに対し，腹腔鏡 所見でEPSと診断されなかった症例をNon-EPS 群（NEPS群， $\mathrm{n}=28 ）$ とした。

次に，このEPS群の病態を明らかにするために NEPS群と比較検討した。

\section{2 ) EPS群とNEPS群の臨床病理学的所見の検} 討

a. 患者背景因子：Table 2 に結果を示す。
Table 2 Clinical findings in EPS vs NEPS

\begin{tabular}{|c|c|c|c|}
\hline & $\begin{array}{l}\text { EPS } \\
(n=4)\end{array}$ & $\begin{array}{l}\text { NEPS } \\
(n=28)\end{array}$ & $p$-value \\
\hline Age & $41.8 \pm 8.3$ & $49.1 \pm 11.8$ & NS \\
\hline $\begin{array}{l}\text { Gender male } \\
\text { female }\end{array}$ & $\begin{array}{l}2 \\
2\end{array}$ & $\begin{array}{c}22 \\
6\end{array}$ & NS \\
\hline $\begin{array}{r}\text { History of CAPD } \\
\text { (months) }\end{array}$ & $144.8 \pm 20.9$ & $80.6 \pm 48.8$ & $p<0.05$ \\
\hline $\begin{array}{r}\text { Past history of } \\
\text { peritonitis (+) } \\
(-)\end{array}$ & $\begin{array}{l}3(75 \%) \\
1\end{array}$ & $\begin{array}{l}11(39.3 \%) \\
17\end{array}$ & NS \\
\hline $\begin{array}{r}\text { Abdominal CT } \\
\text { calcification (+) } \\
(-)\end{array}$ & $\begin{array}{l}4(100 \%) \\
0\end{array}$ & $\begin{array}{l}1(3.5 \%) \\
27\end{array}$ & $p<0.05$ \\
\hline
\end{tabular}

Table 3 Laparpscopic findings in EPS vs NEPS

\begin{tabular}{|c|c|c|c|}
\hline & $\begin{array}{l}\text { EPS } \\
(n=4)\end{array}$ & $\begin{array}{l}\text { NEPS } \\
(n=28)\end{array}$ & $\mathrm{p}$-value \\
\hline Thickening (+) & $3(75 \%)$ & $3(10.7 \%)$ & $0<0.05$ \\
\hline$(-)$ & 1 & 25 & \\
\hline $\begin{array}{r}\text { Adhesion }(+) \\
(-)\end{array}$ & $\begin{array}{l}2(50 \%) \\
2\end{array}$ & $\begin{array}{l}1(3.6 \%) \\
27\end{array}$ & $p<0.05$ \\
\hline Caramel & & & \\
\hline $\begin{array}{r}\text { change (+) } \\
(-)\end{array}$ & $\begin{array}{l}3(75 \%) \\
1\end{array}$ & $\begin{array}{l}9(32.1 \%) \\
19\end{array}$ & NS \\
\hline
\end{tabular}

EPS群とNEPS群において年齢, 性別に有意な差 を認めなかった。EPS群の腹膜透析歴は144.8土 20.9力月と, NEPS群80.6 4 力8.8力月に比べ, 有意 に長期にわたっていた（ $\mathrm{p}<0.05 ）$ 。また，CAPD カテーテルによる腹膜炎既往の有無については有 意な差を認めなかった。

b．腹部CT検查所見：Table 2 に結果を示す。 EPS群では腸管漿膜に石灰化（中～高度）を認め たものは全例であったのに対し，NEPS群では28 例中 1 例に石疢化（軽度）を認めたのみで，石灰 化所見について有意な差が認められた（ $\mathrm{p}<$ $0.05)$ 。

c . 腹腔鏡所見：Table 3 に結果を示す。腸管 漿膜の肥厚は，EPS群 3 例 (75\%)，NEPS群 3 例 $(10.7 \%)$ にみられ，有意な差が認められた $(\mathrm{p}<$ 0.05 )。癒着所見 (手術後の癒着は除く) について も, EPS群 2 例 (50\%), NEPS群 1 例 $(3.6 \%)$ と 有意な差がみられた $(\mathrm{p}<0.05)$ 。しかし，カラメ 儿化は，EPS群 3 例 (75\%)，NEPS群 9 例 (32.1 \%)にみられ，両群に明らかな差は認められなか った。

d. 腹膜病理所見：Table 4 に結果を示す。壁 側腹膜の硝子化については，EPS群が全例（100 \%)にみられたのに対し, NEPS群は 5 例 (17.9\%) 
腹膜透析患者における腹腔鏡所見一特に被囊性腹膜硬化症の病態一

Table 4 Pathological findings of peritoneum in EPS vs NEPS

\begin{tabular}{ccccc}
\hline & EPS & NEPS & p-value \\
& & $(n=4)$ & $(n=28)$ & - \\
\hline Hyalinization $(+)$ & $4(100 \%)$ & $5(17.9 \%)$ & p<0.05 \\
Fibrosis & $(-)$ & 0 & 23 & \\
& $(+)$ & $4(100 \%)$ & $26(92.9 \%)$ & NS \\
& $(-)$ & 0 & 2 & \\
\hline
\end{tabular}

と両群で有意な差が認められた $(\mathrm{p}<0.05)$ 。一方, 線維化については, EPS群 4 例 (100\%), NEPS群 26例 $(92.9 \%)$ にみられ，明らかな差は認められ なかった。

\section{考察}

今回われわれは，腹膜透析患者のCAPDカテー テル抜去を腹腔鏡下に施行し，腹腔内を肉眼的に 観察した。その結果，肉眼的に腹膜の変化は壁側 腹膜に比べ，臟側腹膜（腸管漿膜）に多く認めら れた。その理由は，腸管漿膜のほうがフィブリン を含む血漿成分の滲出, 漏出が起こりやすく，ま た，一定期間，相互に密着することで，血漿成分 が凝固し，被膜を形成しやすいからではないかと 推測されている4)。また, 腸管漿膜の肉眼的変化を カラメル化, 肥厚, 被襄化, 癒着という要素とし て観察したところ，カラメル化はCAPD歴の短い 症例にも認められ, CAPD早期に出現する可能性 のある変化と考之られ，腸管漿膜の肥厚や被囊化 とは独立した因子と考之られた。カラメル化に対 し, 肥厚や被囊化はCAPD歴の長い症例に認めら れ，ほぼ同時期に進行しており，被囊化は漿膜肥 厚の進行過程で明らかになってくるものと推測さ れた。

従来, 腹膜劣化の指標として, 腹膜平衡試験 (peritoneal epuilibration test; PET), 生化学 的パラメーター (CA125, ヒアルロン酸, IL-6, コラーゲン代謝産物など), 腹膜中皮細胞診, 腹膜 組織所見などを用い，間接的に腹腔内の変化を推 測していたが，今回，腹腔鏡により直接観察する ことができた。今後，腹腔鏡により腹膜透析に伴 う腹膜の変化がより正確に把握できると期待され る。

被囊性腹膜硬化症 (encapsulating peritoneal sclerosis；EPS）は硬化性被囊性腹膜炎（scleros- ing encapsulating peritonitis：SEP) ともいわ れ, 1980年Gandhi ${ }^{5)}$, Denisら ${ }^{6)}$ により報告されて 以来，諸家の報告がなされている7) 12)。

その疾患の概念は，臨床的には長期にわたる CAPDによってび慢性に肥厚した腹膜の広範な癒 着により持続的，間欠的あるいは反復性にイレウ 又症状を呈する症候群である。そして，肉眼的に は腹膜肥厚を，組織学的には腹膜線維症もしくは 硬化症として認められる1)とされている。

発症率は全CAPD患者の $1.7 \%$ で2)，5年以上継 続している長期CAPD患者中の $8.0 \%{ }^{13)}$ と報告さ れている。しかし,川西ら ${ }^{13)} の$ 全国調査によると一 度EPSを発症すると106例中52例が死亡し，予後 不良の重篤な経過をたどる疾患であることが示さ れている。

EPSの成因については，透析液中に含まれる高 濃度のグルコース（除水のための浸透圧物質）と その分解産物，および安定化のために酸性に調整 された透析液が腹膜を障害し硬化すると考之られ ている ${ }^{14)}$ 。さらに, 感染や腹膜中皮細胞の修復を阻 害する $\beta$ 遮断薬の使用などが相乗効果となり, 長 期のCAPD療法中に腹膜の線維化・硬化を来たす と報告されている ${ }^{14)}$ 。 EPSは長期の腹膜透析の結 果, 腹膜の劣化が起こり, いわゆる腹膜肥厚の状 態となる。この腹膜肥厚に何らかの炎症細胞浸潤 を伴い，硬化性腹膜炎となる。そして，そのよう な腹膜を呈した腸管が何らかの機序で癒着かつ被 膜によって覆われることでEPSは完成するとさ れている14)。

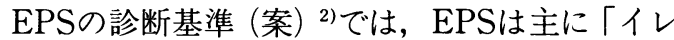
ウス症状が必発である」という臨床症状により診 断され，CT検査などによる画像診断はあくまでも 補助診断に有用とされている。今回，われわれが 腹腔鏡下にCAPDカテーテルを抜去した32例全例 に明らかなイレウス症状は認めなかった。しかし， 明らかなイレウス症状を呈さない症例において も，実際の腹腔鏡所見ではEPSの疾患概念に該当 する（腹腔鏡所見で腸管漿膜に被囊化を認める） 症例が 4 例認められた。また腹腔鏡などの肉眼的 所見も診断に有用とされているが，CAPD施行症 例に対する腹腔所見について系統的に腹腔鏡を用 いて検討した報告は少ない1)。 
今回われわれのEPS群とNEPS群との比較検討 から, 以下の結果が得られた。

1. EPS群では腹膜透析歴が144.8 20.9 力月と NEPS群80.6土48.8力月に比べ有意に長期に わたっていた。

2. 腹部CT検査でEPS群では全例に腸管漿膜に 中等度以上の石灰化が認められた。

3. 腹腔鏡では, EPS群では腸管漿膜の肥厚・癒 着が高率に認められた。

4. 腹膜病理所見では, EPS群全例に壁側腹膜の 硝子化がみられた。

以上より，イレウス症状を呈していない症例に 対しても，EPSの診断に腹腔鏡所見が有用である ことが示唆された。

EPSは, 腹膜透析療法の最終的かつ致死的合併 症である。よって, 今後はEPSに移行する前に腹 部CT検查所見や腹腔鏡所見を定期的に検討し， CAPDからHDへの移行時期の判定ができれば， EPS発症の予防につながるのではないかと考之 られた。

\section{結語}

今回，われわれは腹腔鏡により腹膜透析に伴う 腹膜（特に腸管漿膜）の変化が肉眼的に把握でき ることを確認した。

また, 被囊性腹膜硬化症は腹膜透析 10 年以上に 多く, 腸管漿膜の肥厚や被囊化により腸管癒着が 生じ, その壁側腹膜は硝子化していることが示め された。

\section{謝辞}

本論文報告にあたり，ご協力をいただいた当教 室員, 腎臓内科教室員ならびに病理学第一教室員 の皆様に深謝します。

\section{参考文献}

1）岩本則幸：CAPD患者の腹腔鏡所見. 透析strategy $6: 35-47,2002$

2）野本保夫, 川口良人, 酒井信治他：硬化性被襄性 腹膜炎 (sclerosis encapsulating peritonitis, SEP）診断・治療指針（案）－1997年における改 訂一。目透析医学会誌 $31: 303-311,1998$
3）坂本一博, 小林 滋, 鶴丸昌彦他：腹腔鏡下腹膜 透析カテーテル再留置術の経験。日内視鏡外会誌 $3: 240-245,1998$

4）本田一穂：被䡛性腹膜硬化症の発症とその対策 一サイトカイン発現と腹膜線維化防止法一. 臨透 析19:547-554, 2003

5) Gandhi VC, Humayan HM, Ing TS, et al : Sclerotic thickening of the peritoneal membrane in maintenance peritoneal dialysis patients. Arch Intern Med $140: 1201-1203,1980$

6) Denis J, Paineau J, Potel G, et al : Continuous ambulatory dialysis. Ann Intern Med $93: 508$, 1980

7) Slingeneyer A, Mion C, Mourad G, et al: Progressive sclerosing peritonitis: $\mathrm{A}$ late and severe complication of maintenance peritoneal dialysis. Trans Am Soc Artif Intern Organs 29 : 633-638, 1983

8) Rottembourg J, Issad B, Langlois P, et al : Loss of ultraffiltration and sclerosing encapsulating peritonitis during CAPD. Evaluation of the potential risk factor. Adv Perit Dial. Peritoneal Dialysis Bulletin Inc, Tronto, 1985, 109117

9) Holland P:Sclerosing encapsulating peritonitis in chronic ambulatory peritoneal dialysis. Clin Radiol $41: 19-23,1990$

10) Hollman AS, McMillan MA, Briggs JD, et al: Ultrasound changes in sclerosing peritonitis following continuous ambulatory peritoneal dialysis. Clin Radiol 43 : 176-179, 1991

11) Korzets A, Korzets $Z$, Peer G, et al : Sclerosing peritonitis. Possible early diagnosis by computerized tomography of the abdomen. Am J Nephrol 8 : 143-146, 1988

12) Dobbie JW : Pathogenesis of peritoneal fibrosing syndromes (sclerosing peritonitis) in peritoneal dialysis. Perit Dial Int $12: 14-27,1992$

13）川西秀樹, 川口良人：硬化性被䡛性腹膜炎 (SEP) の全国調查一1998年11月の結果一. 督と透析 第 49巻, 別冊 腹膜透析, 東京医学社, 東京, 2000 , 225-228

14) Pollock CA:Diagnosis and management of encapsulating peritoneal sclerosis. Perit Dial Int $21: \mathrm{S} 61-\mathrm{S} 66,2001$ 